\title{
Летние посевы свеклы столовой на юге России
}

\section{Л.А. Кукса, А.Н. Ховрин, Л.Н. Тимакова}

Полевые опыты в условиях юга России позволили уточнить технологические приемы возделывания свеклы столовой. Оптимальный срок посева свеклы столовой для получения корнеплодов с высокой товарностью и закладки их на зимнее хранение в условиях Ростовской области - 5-15 июля. При посеве в этот срок улучшается качество корнеплодов, а выход товарной продукции составляет 84-90\%.

Ключевые слова: свекла столовая, летние посевы, выход типичных маточников, диаметр корнеплода, кольцеватость.

( векла столовая - очень ценная овощная культура. Она уникальна по содержанию биологически и физиологически активных веществ, витаминов, специфических минеральных солей, ценного пигмента бетанина и азотного вещества бетаина, обладающего целебными свойствами. Эта культура в России занимает 64,23 тыс. га, что составляет более 7\% от общей площади под овощными культурами. На территории РФ ее возделывают повсеместно. Наибольшие площади занимает в Центральном, Приволжском и Южном Федеральном округах, в Ростовской области - 2,48 тыс. га [1].

Рекомендуемые сроки посева свеклы столовой в Ростовской области - конец мая начало июня. Период уборки приходится в основном на середину, а в отдельные годы и на конец сентября. При коротком вегетационном периоде современных сортов вырастить товарную продукцию, предназначенную для хранения в зимний период, становится сложным. Корнеплоды перерастают, имеют уродливый вид, как следствие, падает их товарность.

Для получения качественной товарной продукции корнеплодов на юге России, с ранним сроком созревания и сохранностью в зимний период целесообразно проводить посев в летние сроки.

Цель работы: определить оптимальный срок посева свеклы столовой одно-двухсемянных отечественных сортов для получения товарных корнеплодов, пригодных к длительному хранению.

Экспериментальную работу проводили в 2014-2016 годах на полях селекционного севооборо- та ССЦ «Ростовский» Агрохолдинга «Поиск», расположенном в слободе Красюковская Ростовской области. Материалом служили однодвуростковые сорта свеклы столовой Хуторянка, Двусемянная ТСХА и Бордо односемянная.

Почва в опытах - североприазовская разновидность чернозема обыкновенного. Мощность гумусового горизонта до 70 см. Реакция пахотного слоя нейтральная, содержание гумуса - 4-6\%, валового фосфора - 0,11-0,13\%, валового калия 2,2-2,4\%. Климат континентальный. Продолжительность теплого периода (периода с температурой воздуха выше $0{ }^{\circ} \mathrm{C}$ ) составляет 230-260 суток. Безморозный период длится 160170 суток. Относительная влажность воздуха имеет ярко выраженный годовой ход. Годовое количество осадков колеблется от 300 до 500 мм [2].

В 2014-2016 годах среднемесячная температура не сильно отличалась от среднемноголетней. Весна была довольно ранней, количество осадков в марте было очень низким, апрель и май, наоборот, выдавались очень дождливыми, количество осадков за эти месяцы превосходило среднемноголетние значения, что благоприятно сказалось на появлении всходов первого срока посева. Лето было умеренно жарким.

Исследованияпроводилиметодами полевых и лабораторных опытов, сопровождавшихся сопутствующими анализами [3]. Основные методы наблюдений: визуальный, количественный и количественно-весовой.

Образцы высевали в четырехкратной повторности, площадь учет-

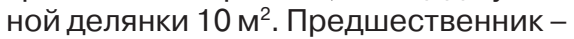
тыквенные культуры. В период ве- гетации проводили наблюдения за ростом и развитием растений. При уборке проводили качественный и количественный учет урожая.

В Ростовской области рекомендованный срок высева семян свеклы столовой для закладки на хранение с 5 по 15 июня [4]. В связи с этим контрольным вариантом в наших опытах является срок посева с 5 по 15 июня.

Схема опыта:

Контрольный срок: с 5 по 15 июня.

1 срок: 20-30 мая - III декада мая.

2 срок: 5-15 июня начало I конец II декады июня - контроль.

3 срок: 20-30 июня - III декада июня.

4 срок: 5-15 июля - начало I конец II декады июля.

5 срок: 20-30 июля - III декада июля.

Урожай учитывали в фазе технической спелости корнеплодов.

Требования к корнеплодам столовой свеклы, реализуемым в розничной торговой сети регламентируются ГОСТ 32285-2013 [5]. Согласно ему размер товарных корнеплодов свеклы столовой по наибольшему поперечному диаметру должен быть 5-10 cм.

При посеве семян свеклы столовой в рекомендуемый для Ростовской области срок (с 5 по 15 июня) и более ранние сроки снижается товарность корнеплодов. Средний размер диаметра корнеплода в первый срок посева (3 декада мая) свыше $11 \mathrm{~cm}$, во второй срок посева свыше $10 \mathrm{~cm}$, что не соответствует требованиям, предъявляемым к товарной продукции свеклы столовой. Переросшие корнеплоды имеют уродливый вид, появляется много треснувших растений, что значительно снижает товарность корнеплодов в эти сроки посева. При неограниченном росте корнеплода увеличивается средний балл кольцеватости от 2 до 3, что также негативно сказывается на качестве продукции.

В более поздние сроки посева свеклы столовой (3 декада июня - 2 декада июля) у сортов увеличивается товарность продукции от 80 до 90\%. При посеве в этот период корнеплоды 
Характеристика корнеплодов свеклы столовой в зависимости от срока посева, 2014-2016 годы

\begin{tabular}{|c|c|c|c|c|}
\hline Сорт & Диаметр корнеплода, см & Товарность маточников,\% & $\begin{array}{c}\text { Выход типичных маточников } \\
\text { с } 1 \text { га, тыс. шт. }\end{array}$ & Кольцеватость, балл \\
\hline \multicolumn{5}{|c|}{ III декада мая } \\
\hline Хуторянка & 11,1 & 22 & 61,6 & 2 \\
\hline Двусемянная ТСХА & 11,5 & 45 & 124,99 & $1-2$ \\
\hline Бордо односемянная & 11,3 & 40 & 110,0 & $2-3$ \\
\hline \multicolumn{5}{|c|}{ I-ІІ декада июня } \\
\hline Хуторянка & 11,3 & 26 & 73,73 & $2-3$ \\
\hline Двусемянная ТСХА & 10,5 & 47 & 131,83 & $1-2$ \\
\hline Бордо односемянная & 10,4 & 54 & 150,33 & $2-3$ \\
\hline \multicolumn{5}{|c|}{ III декада июня } \\
\hline Хуторянка & 10,0 & 51 & 140,0 & $1-2$ \\
\hline Двусемянная ТСХА & 9,6 & 84 & 235,26 & $1-2$ \\
\hline Бордо односемянная & 9,8 & 81 & 224,53 & $2-3$ \\
\hline \multicolumn{5}{|c|}{ I-II декада июля } \\
\hline Хуторянка & 8,2 & 90 & 257,6 & 1 \\
\hline Двусемянная ТСХА & 8,2 & 88 & 244,82 & 1 \\
\hline Бордо односемянная & 8,2 & 84 & 233,8 & $1-2$ \\
\hline \multicolumn{5}{|c|}{ III декада июля } \\
\hline Хуторянка & 5,0 & 11 & 30,80 & - \\
\hline Двусемянная ТСХА & 4,9 & 11 & 29,40 & - \\
\hline Бордо односемянная & 4,9 & 10 & 26,6 & 1 \\
\hline $\mathrm{HCP}_{05}$ & 1,3 & 16,5 & 46,4 & \\
\hline
\end{tabular}

у сортов имели правильную округлую форму, товарный внешний вид, а в мякоти слабо проявлялась кольцеватость. Однако при сроке посева в 3 декаду июня у сорта Хуторянка выход товарных корнеплодов составляет лишь $51 \%$, в связи с перерастанием корнеплода. То есть посев этого сорта следует проводить не ранее начала июля.

При позднем сроке посева корнеплоды к моменту уборки не успели сформировать товарный корнеплод - 5 см у сорта Хуторянка и менее 5 см Двусемянная ТСХА и Бордо односемянная. Товарность корнеплодов в этом варианте составила $10-11 \%$.

Таким образом, оптимальный срок посева свеклы столовой одноростковых сортов для зимнего хранения в условиях Ростовской области - 5-15 июля. При посеве в этот период улучшается качество корнеплодов, а выход товарной продукции составляет 84-90\%.

\section{Библиографический список}

1.Выращивание столовой свеклы в России, данные по регионам [Электронный ресурc]. URL: https://abcentre.ru/news/vyraschivanie-stolovoy-svekly-v-rossiidannye-po-regionam. Дата обращения: 29.09.2019.

2.Агафонов Е.В., Полуэктов Е.В Почвы и удобрения в Ростовской области. Учебное пособие. Персиановка, 1999. 90 с.

3.Методика опытного дела в овощеводстве и бахче- водстве. Под ред. В.Ф. Белика. М.: Агропромиздат, 1992. 319 c.

4.Рекомендации по производству высоких урожаев семян капусты, столовых корнеплодов и репчатого лука. Новочеркасск: ГНУ БОСОС, 1977. 26с.

5.ГОСт 32285-2013. Свекла столовая свежая, реализуемая в розничной торговой сети. Технические условия [Электронный ресурc]. URL: http://docs.cntd.ru/ document/1200108369/ Дата обращения: 17.09.19.

\section{Об авторах}

Кукса Людмила Александровна, м.н.с., Бирючекутская ОСОС - филиал ФГБНУ ФНЦО, агроном «ССЦ Ростовский» Агрохолдинга «Поиск». E-mail: yusupova.Iyuda88@mail.ru Ховрин Александр Николаевич, канд. с. - х. наук, доцент, гл.н.с., зав. отделом селекции и семеноводства, ВНИИО-филиал ФГБНУ ФНЦО, руководитель службы селекции и первичного семеноводства Агрохолдинга «Поиск».

E-mail: hovrin@poiskseeds.ru

Тимакова Любовь Николаевна, канд. с. - х. наук, с.н.с. отдела селекции и семеноводства, ВНИИО-филиал ФГБНУ ФНЦО, селекционер Агрохолдинга «Поиск».

E-mail: Ijubovtimakova@rambler.ru

Summer crops of red beet in the south of Russia

L.A. Kuksa, junior research fellow,

Biryuchekutskaya vegetable breeding experimental station - branch of FSBSI
FSCV, agronomist of Breeding centre Rostovskiy, Poisk Agro Holding.

E-mail: yusupova.lyuda88@mail.ru

A.N. Khovrin, PhD, associate professor, leading research fellow, head of department of breeding and seed growing, All-Russian Research Institute of Vegetable Growing branch of FSBSI Federal Scientific Centre of Vegetable Growing, head of department of breeding and primary seed production of Poisk Agro Holding.

E-mail: hovrin@poiskseeds.ru

L.N. Timakova, $P h D$, senior research fellow, laboratory of breeding of root crops and onions, department for breeding and seed growing, All-Russian Research Institute of Vegetable - branch of FSBSI Federal Scientific Centre of Vegetable Growing, breeder of Poisk Agro Holding. E-mail: ljubovtimakova@rambler.ru

Summary. In the conditions of field experiments the technological methods of seed growing of table beet in the conditions of the South of Russia are specified. The optimal period of red beet sowing for root crops with high marketability producing for winter storage in the Rostov region is 5-15 of July. When sowing in this period, the quality of root crops improves, and the yield of marketable products is $84-90 \%$.

Keywords: red beet, summer crops, the output of typical queen cells, the diameter of the root crop, ringiness. 